\title{
Epizootic mortality in the pilchard Sardinops sagax neopilchardus in Australia and New Zealand in 1995. II. Identification of a herpesvirus within the gill epithelium
}

\author{
A. D. Hyatt ${ }^{1, *}$, P. M. Hine ${ }^{2}$, J. B. Jones ${ }^{3}$, R. J. Whittington ${ }^{4}$, C. Kearns ${ }^{4}$, T. G. Wise ${ }^{1}$, \\ M. S. Crane ${ }^{1}$, L. M. Williams ${ }^{1}$ \\ 'Australian Animal Health Laboratory, CSIRO, PO Bag 24, Geelong, Victoria 3220, Australia \\ ${ }^{2}$ National Institute for Water and Atmospheric Research, PO Box 14-901, Wellington, New Zealand \\ ${ }^{3}$ Fisheries Department of Western Australia, Animal Health Laboratories, 3 Baron-Hay Court, South Perth, \\ Western Australia 6151, Australia \\ ${ }^{4}$ New South Wales Agriculture, Elizabeth Macarthur Agricultural Institute, Private Bag 8, Camden, NSW 2570, Australia
}

\begin{abstract}
Mass mortalities among pilchards Sardinops sagax neopilchardus occurred around Australia and New Zealand from March to September 1995. The mortalities spread rapidly both with and against currents and usually affected fish longer than $11 \mathrm{~cm}$. Examination showed mortalities to be associated with the presence of replicating herpesvirus in the gill epithelium; herpesviruses were not observed within equivalent cells of unaffected fish collected ahead of the mortality front. By negative contrast electron microscopy the virus was demonstrated to possess a $96 \mathrm{~nm}$ icosahedral capsid containing 162 capsomers. Many virions were enveloped and possessed surface projections. The nuclei of infected epithelial cells contained nucleoids, capsids and nucleocapsids which were released from the nucleus into the surrounding cytoplasm following degeneration of the nuclear membrane. Within the cytoplasm, the capsids and nucleocapsids acquired a tegument and subsequently were enveloped by passing into smooth-surfaced vesicles or by budding from the plasma membrane. Release of viruses from the cells was, in the main, associated with lysis of infected gill epithelial cells. The morphology of the virus and ultrastructure of infected cells suggest that this virus belongs to the family Herpesviridae. The presence of a replicating herpesvirus within the gill epithelium is discussed in context with the epizootic
\end{abstract}

KEY WORDS: Clupeoidae Pilchard Sardinops sagax neopilchardus Gill diseases Electron microscopy Herpesvirus

\section{INTRODUCTION}

Mortality in pilchards Sardinops sagax neopilchardus occurred in southern Australian and New Zealand coastal waters in 1995 (described in the companion paper, Whittington et al. 1997). The mortalities commenced in March 1995 in South Australia from an area known as Anxious Bay on the Eyre Peninsula. The

\footnotetext{
·E-mail:alex@aahl.dah.csiro.au
}

mortality front then progressed in easterly and westerly directions at rates varying from 1.3 to $43 \mathrm{~km} \mathrm{~d}^{-1}$, often against prevailing currents (Whittington et al. 1997). By May, the mortalities had reached the southwestern tip of Western Australia and New South Wales (NSW) waters and by June had progressed as far as southern Queensland. During June, similar mortalities had commenced on the north east coast of New Zealand (Whittington et al. 1997). During June, pilchards began dying in Hauraki Gulf, North Island, New Zealand and by mid-July mortalities had spread 
northwards along the coast to Cape Reinga and a few days later to Ninety Mile beach. Mortalities ceased around Australia by August but in New Zealand mortalities occurred around the North and South Islands up to September 1995 (Whittington et al. 1997). It is estimated that in Western Australian waters at least $10 \%$ of the pilchard population died during the epizootic. The proportion was probably greater than $10 \%$ as divers recorded many fish sinking to the sea floor soon after death (Whittington et al. 1997). Mortalities in other species of finfish were not recorded.

During the epizootic, dying pilchards were seen swimming slowly and erratically, lying on their sides at the surface, leaping out of the water, or surfacing vertically until the head was out of the water and then sinking tail first (Whittington et al. 1997). Upon stimulation, many fish within the affected schools would shudder violently, then die and float to the surface before sinking to the bottom. Some pilchard schools appeared affected while others in close proximity appeared unaffected. The affected schools were comprised of fish longer than $11 \mathrm{~cm}$.

There has been only one other report of pilchard mortalities in Australia. That report (Copas 1982) describes pilchards, 15 to $25 \mathrm{~cm}$ long, which were washed ashore at Hawley Beach, Northwest Tasmania. The mortalities were restricted to one location and, by comparison, affected only small numbers of fish. The clinical signs associated with these mortalities, burst stomachs and haemorrhage from the gills and anus, also suggest a different aetiology. In New Zealand, intermittent pilchard mortalities have been reported since 1900-1902 (Graham 1974) but the cause of these mortalities is not known. More recently isolated and sporadic mortalities were reported from the Bay of Islands, New Zealand (April 1996), Waiuku Beach, New Zealand (March 1995), and Wellington Harbour, New Zealand (December 1993), but these deaths involved mixed species of baitfish, discards from fishers and the involvement of the microalga Tetraselmis (Smith 1995). These pre-June mortalities in New Zealand have a different epizootiology and do not appear to be related to the epizootic which occurred from June through September 1995 in which mortalities spread in a wave-like pattern with and against currents, covered large geographical distances and affected substantially more pilchards.

Pilchards associated with the current epizootic showed gill pathology suggestive of a common aetiology (Whittington et al 1997). The pathology was confined to gill lesions and comprised of acute to subacute inflammation followed by epithelial hypertrophy and hyperplasia. Histological examination of the affected pilchards revealed that the disease had a logical progression and the observed pathology could contribute to the observed hypoxaemia and hypercapnea. The patholgy was not consistent with an insult from ichthyotoxic algae, siliceous algae, physiochemical factors, fungi, bacteria, dinoflagellates, amoebae, other protozoa or metazoa. The results were however suggestive that an infectious agent was involved.

This paper reports the results from extensive electron microscopical investigations into the identification. of an infectious aetiological agent associated with all the massive pilchard mortalities around Australia and New Zealand.

\section{MATERIALS AND METHODS}

Specimen collection. Pilchards were collected for laboratory examination from a range of locations around southern Australia and the North Island of New Zealand; the collection sites are detailed by Whittington et al. (1997). Specimens from areas where mortalities had been observed were sampled from masses of dead and moribund fish floating on the surface or were netted from live and apparently healthy schools. Specimens of healthy pilchards from waters ahead of the mortality fronts (Table 1) were also collected from around Australia and from Wellington Harbour, North Island, New Zealand. Whole fish and dissected gills were submitted to the laboratories (refer below) on ice, or frozen or in $10 \%(\mathrm{v} / \mathrm{v})$ buffered formalin or $2.5 \%(\mathrm{v} / \mathrm{v})$ glutaraldehyde in filtered $(0.22 \mu \mathrm{m})$ seawater. All samples were processed for examination by electron microscopy.

Processing of samples for electron microscopy. Samples were received at the Australian Animal Health Laboratory (AAHL, Victoria), the Animal Health Laboratory (AHL, Western Australia), the Elizabeth Macarthur Agricultura] Institute (EMAI, NSW, Australia) and the National Institute for Water and Atmospheric Research laboratory (NIWA, New Zealand). Examination of whole fish and individual organs revealed that lesions were present only within the gills of affected fish. (Whittington et al. 1997). These gills were dissected and processed for the production of ultra-thin sections and/or for negative contrast electron microscopy (NCEM).

For uitra-thin sections, both formalin-and $0.1 \mathrm{M}$ cacodylate ( $\mathrm{pH}$ 7.2)- or $0.1 \mathrm{M}$ phosphate ( $\mathrm{pH}$. 7.2)-buffered $2.5 \%(\mathrm{v} / \mathrm{v})$ glutaraldehyde-fixed samples (submitted to AAHL, EMAI, AHL) were washed in buffer $(0.1 \mathrm{M}$ cacodylate or phosphate, $\mathrm{pH} 7.2$ ), post-fixed in $1 \%$ osmium tetroxide (in buffer), washed in doubledistilled water, dehydrated through a graded alcohol series (70 to $100 \%)$ and embedded in Spurr's resin. Alternatively, samples (submitted to NIWA) were fixed in $2.5 \%(\mathrm{v} / \mathrm{V})$ glutaraldehyde in filtered seawater (FSW) for $1 \mathrm{~h}$, washed twice in FSW, post-fixed as above and embedded in Araldite or Epon 812. All sec- 
Table 1. Location and virus status of pilchards submitted for examination by electron microscopy

\begin{tabular}{|c|c|c|c|}
\hline Location & $\begin{array}{c}\text { Stage of mortality } \\
\text { event }\end{array}$ & $\begin{array}{l}\text { No. of fish } \\
\text { examined }\end{array}$ & $\begin{array}{l}\text { Presence } \\
\text { of virus }^{\text {t }}\end{array}$ \\
\hline Geelong, Victoria & During & 1 & 1 \\
\hline Iluka, NSW & $4 \mathrm{~d}$ before & 27 & 0 \\
\hline Iluka, NSW & 2 d before & 5 & 5 \\
\hline lluka, NSW & During & 12 & 11 \\
\hline lluka, NSW & $8 \mathrm{~d}$ after & 16 & 0 \\
\hline Port Stephens, NSW & During & 10 & 8 \\
\hline Foster/Taree, NSW & During & 4 & 3 \\
\hline Port Hacking, NSW & During & 8 & 8 \\
\hline Coffs Harbour, NSW & During & 4 & 4 \\
\hline Esperance, WA & Before & $20^{c}$ & $-v e$ \\
\hline Bremer Bay, WA & During & $20^{c}$ & tve \\
\hline Bremer Bay, WA & $9 \mathrm{~d}$ before & $20^{c}$ & $-v e$ \\
\hline Bremer Bay, WA & $6 \mathrm{~d}$ after & $20^{c}$ & -ve \\
\hline Albany, WA & $5 \mathrm{~d}$ before & $20^{c}$ & $-v e$ \\
\hline Albany, WA & During & $20^{\circ}$ & +ve \\
\hline Albany, WA & $11 \mathrm{~d}$ after & $20^{c}$ & $-v e$ \\
\hline Freemantle,WA & $18 \mathrm{~d}$ before & $20^{\circ}$ & $-v e$ \\
\hline Freemantle, WA & 4 d after & $20^{c}$ & -ve \\
\hline Freemantle, WA & During & $40^{c} \& 6$ & $+v e, 2$ \\
\hline Bunbury, WA & During & $20\ulcorner \& 11$ & +ve, 9 \\
\hline North Beach, WA & During & 3 & 1 \\
\hline Dunsborough, WA & $7 \mathrm{~d}$ before & $20^{c}$ & -ve \\
\hline Rottnest, WA & During & $40^{\mathrm{c}}$ & tve \\
\hline Rockingham, WA & During & $20^{r}$ & $+v e$ \\
\hline Bay of Islands, NZ & During & 15 & 15 \\
\hline Wellington Harbour, NZ & $70 \mathrm{~d}$ before & 8 & 0 \\
\hline Wellington Harbour, NZ & During & 15 & 15 \\
\hline \multicolumn{4}{|c|}{$\begin{array}{l}\text { No of herpesvirus-positive fish } \\
\text { "Sample collected before mortality event but specific date not known } \\
\text { "Pools of gill tissue from approximately } 20 \text { fish were analysed by } \\
\text { NCEM; all other numbers represent individual fish analysed by ex- } \\
\text { amination of ultra-thin sections. Results from NCEM analyses are } \\
\text { tndicated by +ve/-ve. Geographical locations and dates of mortality } \\
\text { events are given in the companion paper, Whittington et al. (1997) }\end{array}$} \\
\hline
\end{tabular}

Wales, and at AHL the samples originated from Western Australia.

At AAHL, chinook salmon embryo (CHSE214; American Type Culture Collection (ATCC) CRL 1681), rainbow trout gonad (RTG-2; ATCC CCL 55), Bluegill fry (BF-2; ATCC CCL 91), Fat Head Minnow (FHM; ATCC CCL 42) and Epithelioma Papulosum Cyprini (EPC) (Fijan et al. 1983) cell lines were used for virus isolation. Briefly, pooled and individual tissue samples (gills, liver, kidney and spleen) were homogenised using a frozen $\left(-20^{\circ} \mathrm{C}\right)$, sterile mortar. For each pool $(n=245)$, the disrupted tissue was suspended in maintenance medium (Earle's Minimal Essential Medium), at a dilution of approximately $1: 10$ and centrifuged $(1600 \times g$ for $15 \mathrm{~min})$. A portion of the supernatant was diluted a further 1:10 with maintenance medium and filtered (Sartorius Minisart NML filters; $0.45 \mathrm{~mm}$ pore size) into sterile tubes. Aliquots $(200 \mu l)$ of each sample were placed on duplicate cell cultures in 24 well culture plates and adsorbed for $1 \mathrm{~h}$ at $15^{\circ} \mathrm{C}$ in an atmosphere of $5 \% \mathrm{CO}_{2} / 95 \%$ air. Following adsorption, maintenance medium was added to each well (up to $2.0 \mathrm{ml}$ ) and cultures incubated at $15^{\circ} \mathrm{C}$ in an atmosphere of $5 \%$ $\mathrm{CO}_{2} / 95 \%$ air. Cultures were examined by light microscopy for a period of up to $21 \mathrm{~d}$ (including one passage onto fresh cell cultures) for the appearance of viral cytopathic effect (CPE)

At EMAI, gills $(n=86)$ were processed separately whilst liver, kidney and spleen were pooled. Samples were processed as

tions were double-stained with lead citrate and uranyl acetate and examined with a Hitachi H600 scanning transmission electron microscope or a Philips CM12, CM10 or 420ST transmission electron microscope at 75 or $80 \mathrm{kV}$

Samples for NCEM were freeze-thawed ( $\times 3$ ), homogenised $(10 \%$ in phosphate-buffered saline, $\mathrm{pH} 7.2$ ) and clarified in a bench centrifuge $(800 \times \mathrm{g}, 10 \mathrm{~min})$. Aliquots of supernatant were then adsorbed to parlodion-filmed, carbon-coated, 400 mesh copper grids and stained with $2 \%(\mathrm{w} / \mathrm{v})$ phosphotungstic acid $(\mathrm{pH}$ 6.8). Preparations were examined in a Hitachi $\mathrm{H} 600$ scanning transmission electron microscope; magnifications were calibrated against catalase crystals and a 2160 lines $\mathrm{mm}^{-1}$ diffracting standard.

Cell culture for virus isolation. Pilchards were submitted to AAHL, EMAI and AHL diagnostic laboratories where virus isolation was attempted. At AAHL, samples (refer below) from Western Australia, NSW, New Zealand and Victoria were processed for virus isolation; at EMAI the samples were from New South described by Whittington \& Steiner (1993). Briefly, the homogenised sample preparation was diluted in homogenising medium (Whittington \& Steiner 1993) to provide final inocula of $1: 10$ and $1: 100$. The inocula were added to tissue culture tubes (Kimax) containing BF-2, RTG-2 and FHM cells (all cell lines ATCC as described above) and incubated at $22^{\circ} \mathrm{C}$. Inoculated $\mathrm{BF}-2$ cells were also incubated at $15^{\circ} \mathrm{C}$. All cultures were incubated in air. At AHL individual samples of gills, kidney, liver and spleen were analysed as described above (EMAI) but were inoculated on RTG-2 cells and incubated at $22^{\circ} \mathrm{C}$.

\section{RESULTS}

\section{Negative contrast electron microscopy of tissue homogenates}

Examination of clarified homogenates from the gills of affected fish revealed the presence of a virus-like particle. The virus was present as naked icosahedral 
capsids approximating $96 \pm 3 \mathrm{~nm}$ in diameter and as enveloped virions which varied greatly in size from 120 to $280 \mathrm{~nm}$ in diameter (Fig 1). Around the periphery of most capsids distinct serrations were obvious (Fig 1A); these corresponded to the side view of capsomers which numbered 5 along any straight edge giving a $T$-number of $16\left[T=(n+1)^{2}\right.$ where $\mathrm{n}=$ number of hexamers between 2 neighbouring pentamers] and a calculated 162 capsomers [10T +2$]$. Capsomers had a mean diameter of $12 \pm 1 \mathrm{~nm}$ and possessed axial holes. The envelope possessed 17 to $19 \mathrm{~nm}$ surface projections which terminated as cylindrical knobs (Fig. 1). Viruses were not observed from homogenates prepared from unaffected (healthy) fish.

\section{Ultrastructural examination of gills from dead and moribund pilchards}

Gills from healthy, dead and moribund pilchards were processed for the production of ultra-thin sections. Examination of these samples revealed an association of herpesvirus with the epithelial cells of the secondary lamellae of dead and moribund pilchards (Fig. 2A). An ultrastructural description of the virus and associated infected cells is detailed below.

The data in Table 1 imply that the virus is associated with fish from affected schools (containing dead and moribund fish) within both Australian and New Zealand waters. Samples submitted for electron microscopical analyses from affected schools contained some fish infected with the virus. In general the prevalence varied from 33 to $100 \%$ (Table 1 ); the lower prevalences may be misleading as the analyses of many fish were limited to the examination of only one ultra-thin section. Of the 162 unaffected pilchards examined (Table 1) only 5 were observed to contain herpesvirus. These 5 samples were collected 2 d before the mortality event at Iluka and were shown to be associated with developing gill lesions (Whittington et al. 1997). Collectively the data indicate that herpesvirus was associated with fish developing gill lesions and with the mortality events in the coastal waters of Australid and New Zealand.

\section{Structure of gills from unaffected fish}

Pilchards were collected $4 \mathrm{~d}$ ahead of the mortality front at Iluka (NSW, Australia), and $70 \mathrm{~d}$ ahead of mortalities from Wellington Harbour, New Zealand (Table 1). The quality of ultrastructural fixation was directly related to the preparation protocol (refer to
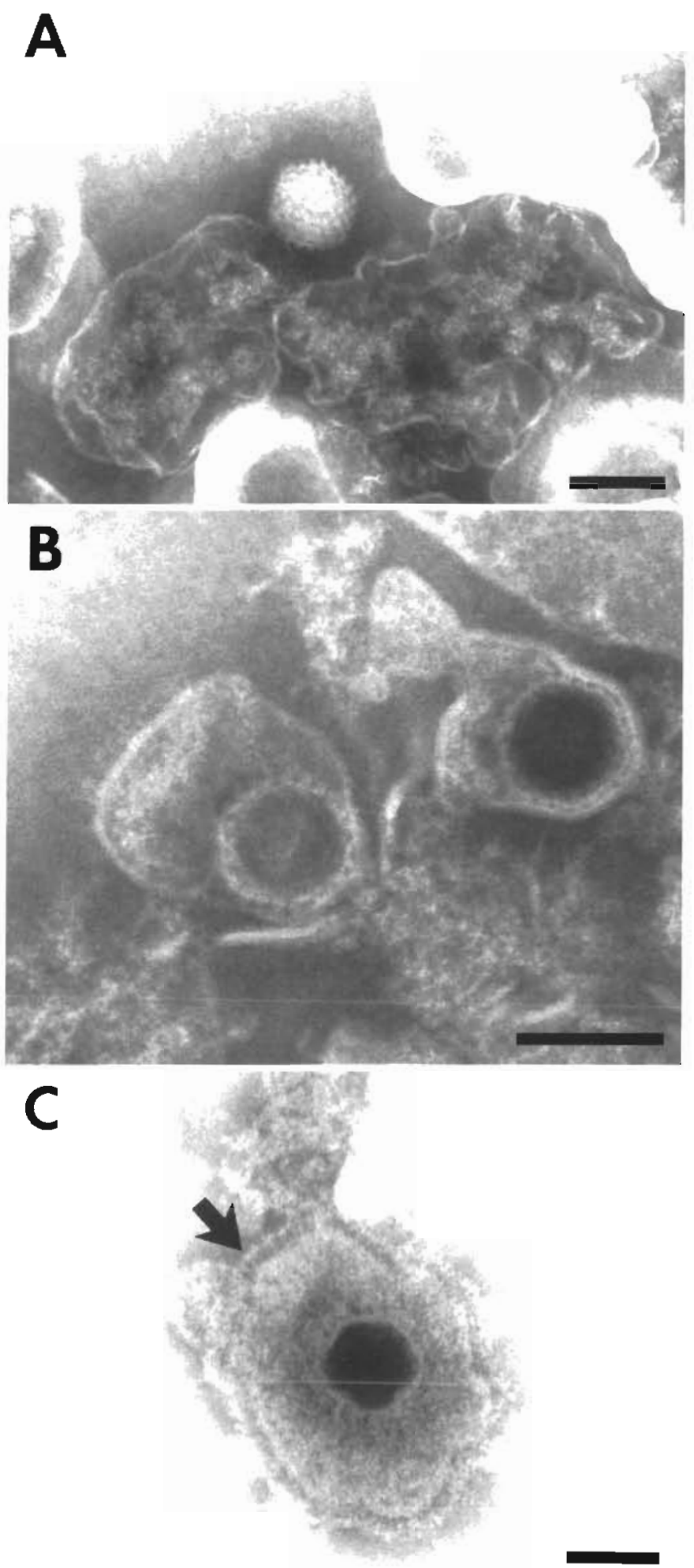

Fig. 1. Electron micrograph of negative-stained herpesviruses within homogenates of pilchard gill epithelium. (A) Naked icosahedral capsid. (B) Enveloped capsids. (C) Enveloped capsid with distinct surface projections; arrow: surface projection with a cylindrical knob. Samples collected from an affected pilchard. Iluka, NSW, Australía. Bars $=100 \mathrm{~nm}$ 
Fig. 2. Sardinops sagax neopilchardus. (A) Transmission electron micrograph of a herpesvirus-infected gill epithelial cell associated with the secondary lamellae from an affected pilchard. Nu: nucleus; ib: intranuclear inclusion body; arrows: virus. Sample collected from an atfected pilchard, Wellington Harbour, New Zealand. Bar $=1 \mu \mathrm{m}$. (B) Primary and secondary gill lamella from an unaffected pilchard. P: pillar cell; $\mathrm{Cl}$ : chloride cell; bl: basal lamina; Ery: erythrocyte; Ep: epithelial cell; bv: blood vessel. Sample collected from an unaffected fish, Wellington Harbour, New Zealand. Bar $=10 \mu \mathrm{m}$

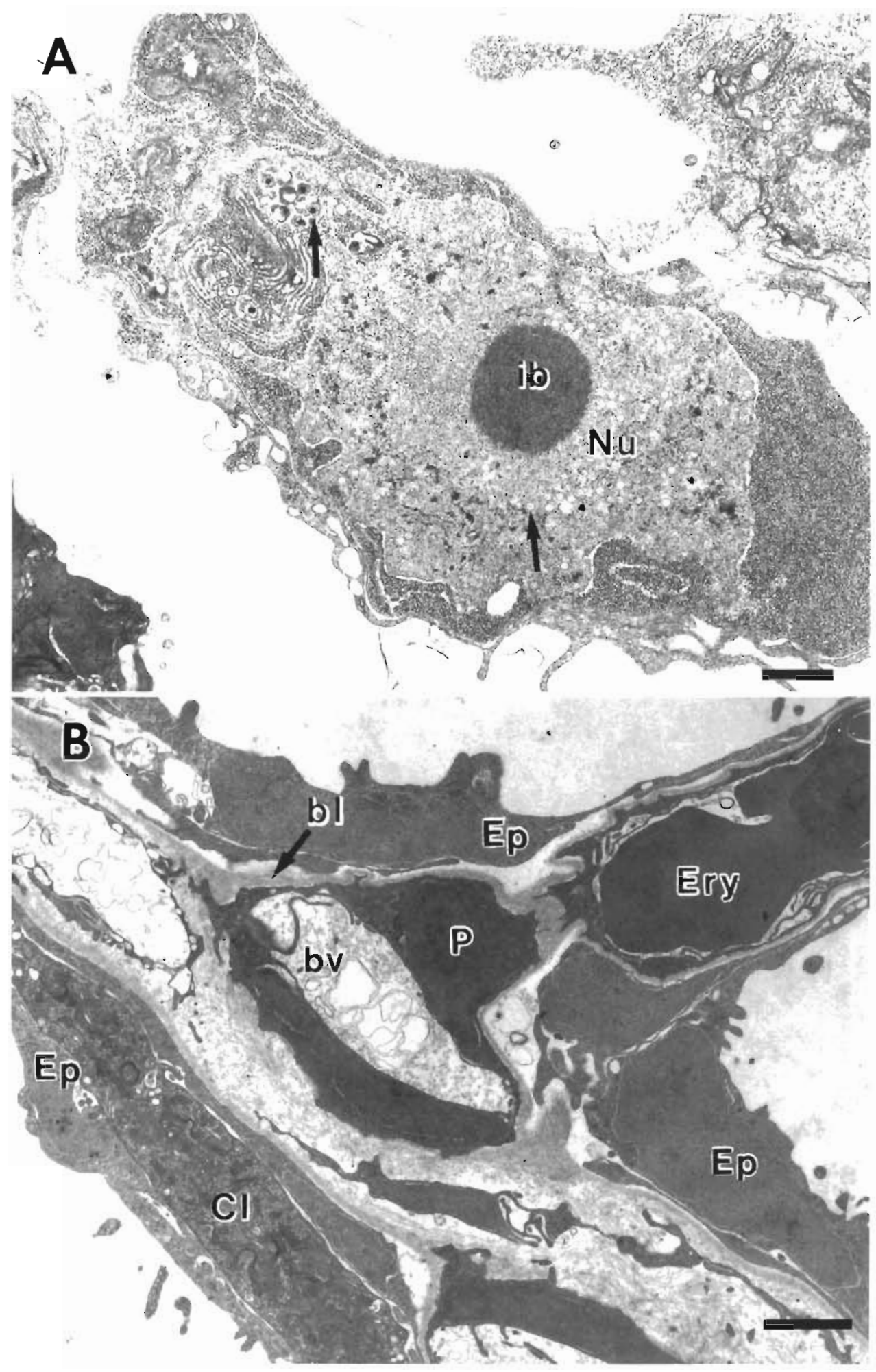

'Materials and methods'). All samples which were frozen exhibited poor ultrastructure but the basic organısation of the gills could be observed. Samples which were frozen and later fixed in $10 \%$ formalin were diffucult to interpret as the surface epithelial layer often dissociated from the underlying basal lamina. Gills which were collected directly into formalın and glutaraldehyde exhibited better ultrastructural preservation with glutaraldehyde-fixed material exhibiting the better fixation. The ultrastructural detall presented below is based, in 
the main, from tissues fixed directly with glutaraldehyde and to a lesser extent $10 \%$ formalin. As samples were submitted for virus exclusion/confirmation, all samples were examined irrespective of the mode of fixation.

Primary and secondary lamellae (Fig. 2B) were covered with a single layer of squamous epithelial cells possessing a dense ribosome-rich cytoplasm and a central ovoid nucleus. Adjoining cells were attached by interdigitations and desmosomes. In the secondary lamellae, these cells were situated over a basal lamina (Fig. 2B) which in turn surrounded pillar cells, the cytoplasm of which enclosed the vascular spaces containing circulating blood cells (Fig. 2B). Chloride cells were observed (Fig. 2B) infrequently between the epithelium and pillar cell extensions but were more numerous in the interlamellar troughs.

Fibroblasts with associated fibres and rodiet cells were observed towards the base of the primary lamellae. Fine granulocytes with elongated rod-like granules, and eosinophilic granulocytes with ovoid granules containing a rod-like core, were also more frequently observed in the primary lamellae, but were never numerous (data not shown).

\section{Structure of gills from affected fish}

The ultrastructure pathology of gills from affected pilchards varied including mild to severe hyperplasia of the secondary lamellae (Fig. 3). However, the sec- ondary lamellae of all affected pilchards contained some epithelial cells which appeared hypertrophic and were infected with herpesviruses; these cells varied in number within any one gill and between individuals. Virus-infected cells appeared to be swollen and to become progressively detached from the adjacent epithelial cells and the underlying basal lamina. Detachment of the cells was frequently accompanied with dissolution or fragmentation of the nuclear and plasma membranes which in turn was associated with cell lysis (Fig. 4). Detached chloride cells (Fig. 5) containing prominent dilated tubular systems were also associated with the disrupted epithelium; occasionally a virus particle was observed within one of these cells.

Many eosinophilic granulocytes were present within the primary and secondary lamellae, where they appeared to be either dense and degenerate or lysed, releasing their characteristic granules. Macrophages, in addition to detached epithelial cells, were also observed within the interlamellar spaces and contained necrotic cell debris and numerous viral capsids (Fig. 6). Many of these capsids contained toroids at different stages of development (Fig. 6).

\section{Virus replication}

A few viral capsids were observed in the tubular system of detached and lysed chloride cells (Fig. 5) and around the debris of chloride cells. Occasional de-

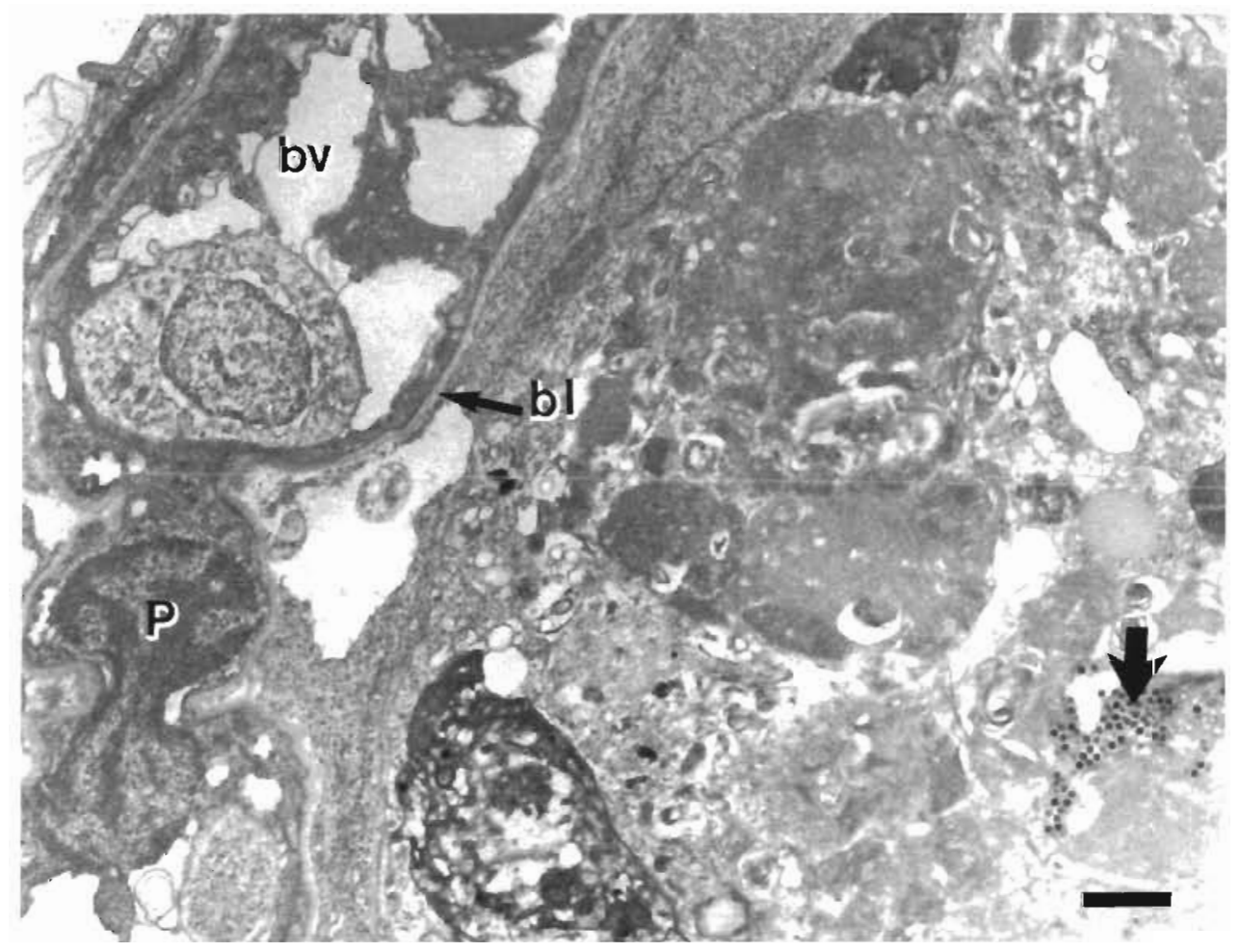

Fig. 3. Sardinops sagax neopilchardus. Transmission electron micrograph of hyperplastic gill epithelium of affected pilchards. The cells adjacent to the basal lamina (bl) are representative of the severe epithelial hyperplasia. P: pillar celli bv: blood vessel; thick arrow: virus. Sample collected from an affected pilchard, Geelong, Victoria, Australia $\operatorname{Bar}=1 \mu \mathrm{m}$ 


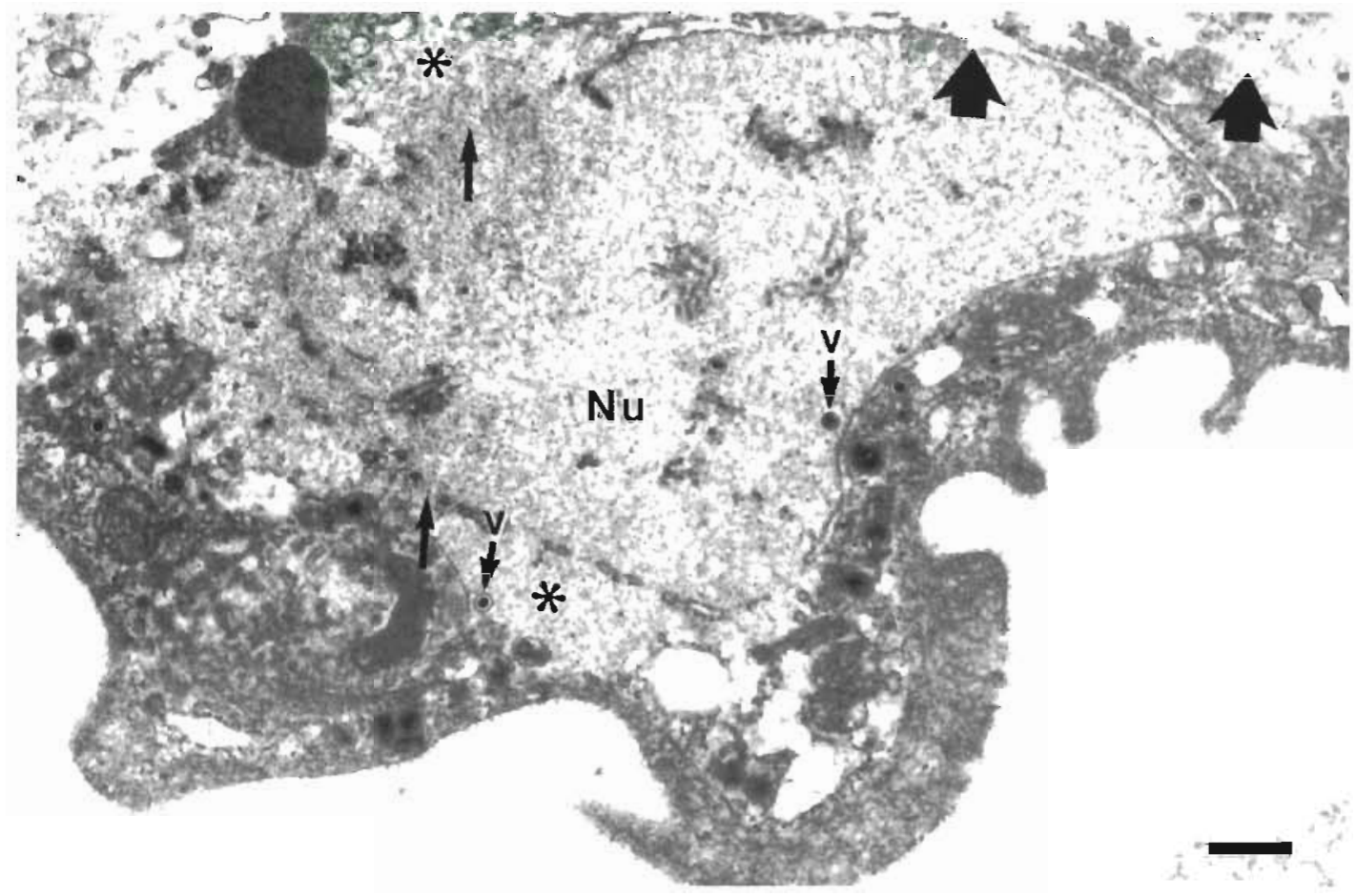

Fig. 4. Sardinops sagax neopilchardus A herpesvirus-infected gull epithehal cell The nuclear membrane has fragmented/ disrupted (arrows) allowing nucleoplasm ( $*$ ) to enter the cytoplasmic compartment Nu nucleus; $v$ virus, thick arrows. areas of cell lysis. Sample collected from an aftected fısh, Wellington Harbour, New Zealand Bar $=500 \mathrm{~nm}$

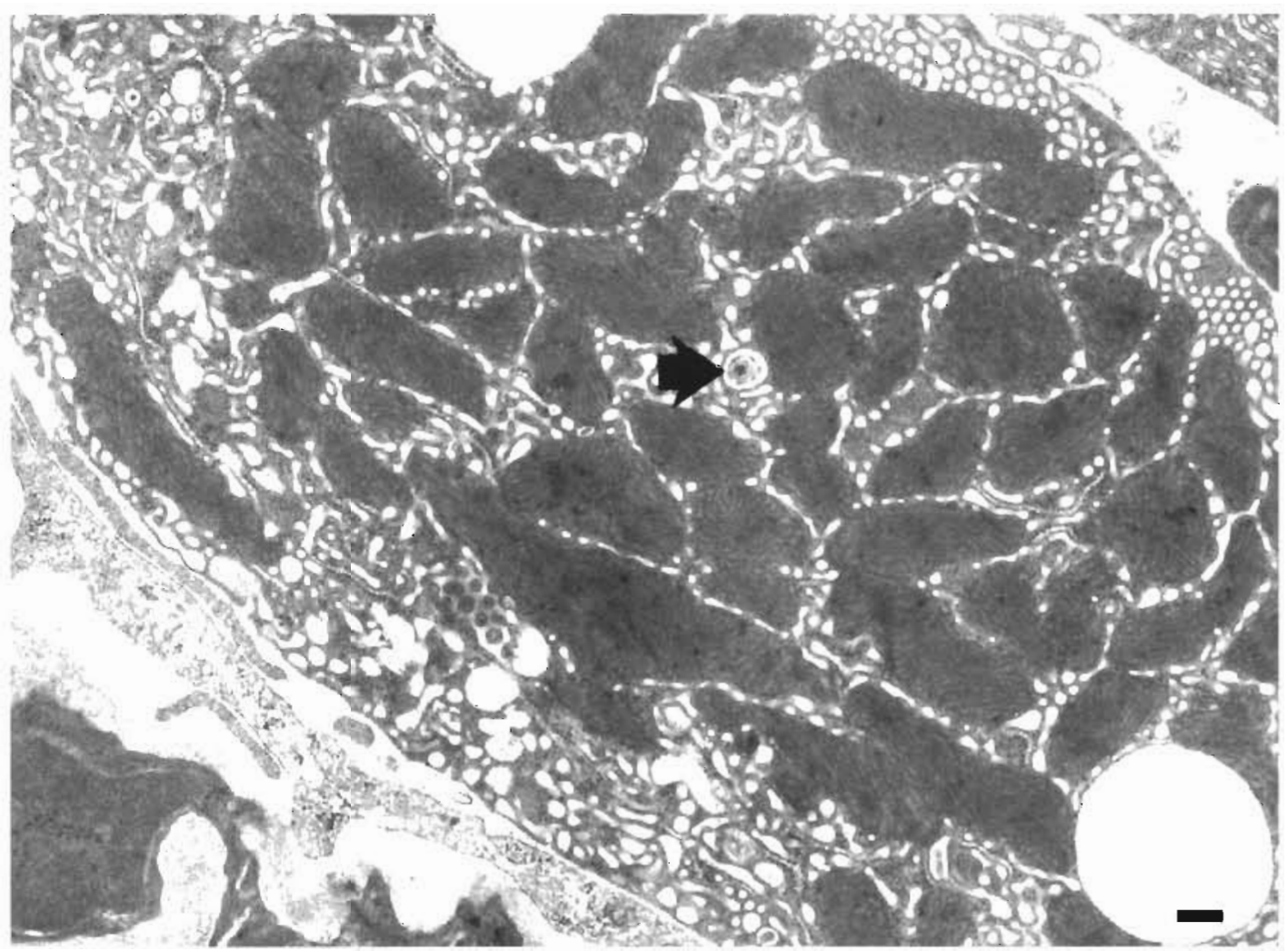

Fig. 5. Sardinops sagax neopilchardus Detached chloride cell from the gill epithelium containing a single herpesvirus (arrow) Sample collected from an affected plichard, Wellington Harbour. New Zealand Bar $=200 \mathrm{~nm}$ 

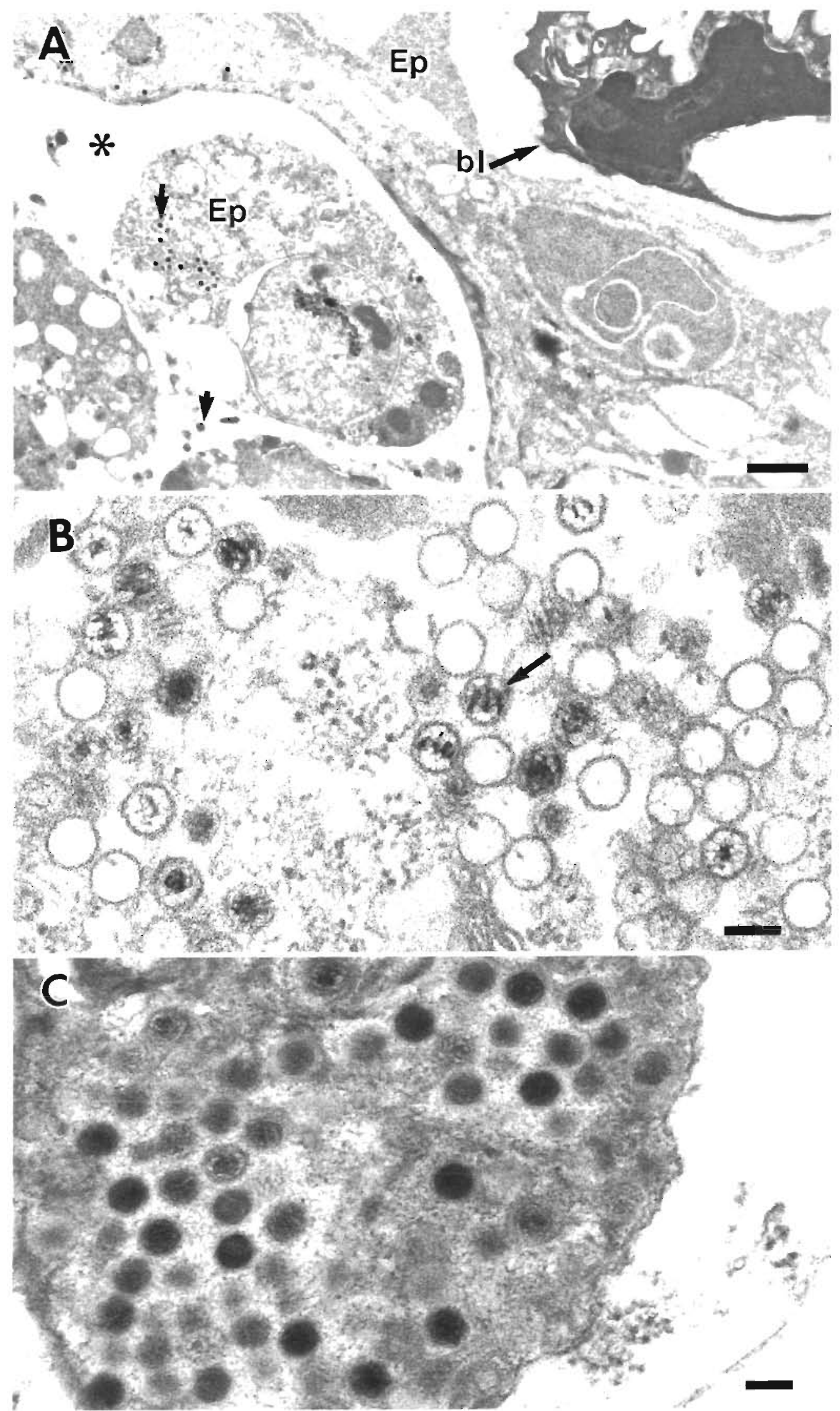

Fig. 6. Sardinops sagax neopilchardus. Detached epithelial cells within the interlamellar spaces $(*)$. (A) Arrows: viruses; Ep: epithelial cell; bl: basal lamina. Sample collected from an affected pilchard, Geelong, Victoria, Australia. Bar $=1 \mu \mathrm{m}$ $(B, C)$ Viruses within a degenerate macrophage; arrow: toroid. Bars = $100 \mathrm{~nm}$. Samples collected from affected pilchards at (B) lluka (NSW Australia), and (C) Bremmer Bay (Western Australia) 
tached mucous cells containing a single virus particle were sometimes observed (data not shown) Virus capsids were never observed within the nuclel of these cells indicating that they did not support replication of the virus.

The nuclei of infected epithelial cells were variable in shape with dilatation of the nuclear membranes $A$ large, ovoid-to-round dark granular inclusion was frequently observed near the centre of the nucleus (Fig. 2A), and electron-dense bodies, $50 \mathrm{~nm}$ in diameter, were present in or near the patches of fine granular material (Figs. 2A \& 4). The presence of the dark. granular inclusion appeared to correlate to the extent of hyperplasia; e.g. epithelial cells which were fixed directly into glutaraldehyde (in seawater) and displayed little hyperplasia often possessed the intranuclear inclusion body whereas epithelial cells in areas of gill exhibiting significant hyperplasia did not. Viral capsids were seen in close proximity to the $50 \mathrm{~nm}$ dense bodies which appeared to enter the capsids to form nucleocapsids. In some nuclel, thread-like structures, possibly from the round dark granular inclusion, appeared to surround nucleoids (Fig 4), The nuclear membrane of some epithelial cells appeared fragmented or could not be resolved (Fig 4) Within some of these cells the nucleoplasm appeared to merge with the cytosol (Fig. 4). Capsids and nucleocapsids were not observed passing through the nuclear membrane.

Capsids ( $95 \pm 3 \mathrm{~nm}, \mathrm{n}=50$ ) and nucleocapsids were frequently observed in the cytoplasm. In many cells they were also located around vesicles containing a very fine electron-dense matrix (Fig 7) Enveloped virions $(147 \pm 12 \mathrm{~nm}, \mathrm{n}=50)$, with a dense tegument similar to that within the above vesicles, were also observed aggregated within small to large vesicles containing flocculent material (Fig 8) These smoothsurfaced vesicles appeared to be associated with the Golg1 system. Virus egress occurred by degeneration of the plasma membrane (cell lysis) and by the budding of capsids and nucleocapsids through the plasma membrane (Figs. 4 \& 9).

\section{Cell culture}

No CPE typical for a herpesvirus was observed in any of the inoculated cell cultures at any of the laboratories. Some homogenates were confirmed by NCEM to contain herpesviruses pnor to inoculation onto BF-2 cell monlayers (EMAI). These cultures did not produce a CPE during either the furst or second passage. Electron microscopical examination of the supernatants and cells from the inoculated cultures also did not reveal the presence of a replicating virus

\section{DISCUSSION}

Replicatıng viruses were observed within the gill epithelium of fish collected from schools of dead and
Fig. 7. Herpesviruses associated with vesicles (arrows) containing an electron-dense matrix (thick arrow). Small arrow: cytoplasmic viruses. Sample collected from an affected pilchard at Wellington Harbour, New Zealand. Bar = $500 \mathrm{~nm}$

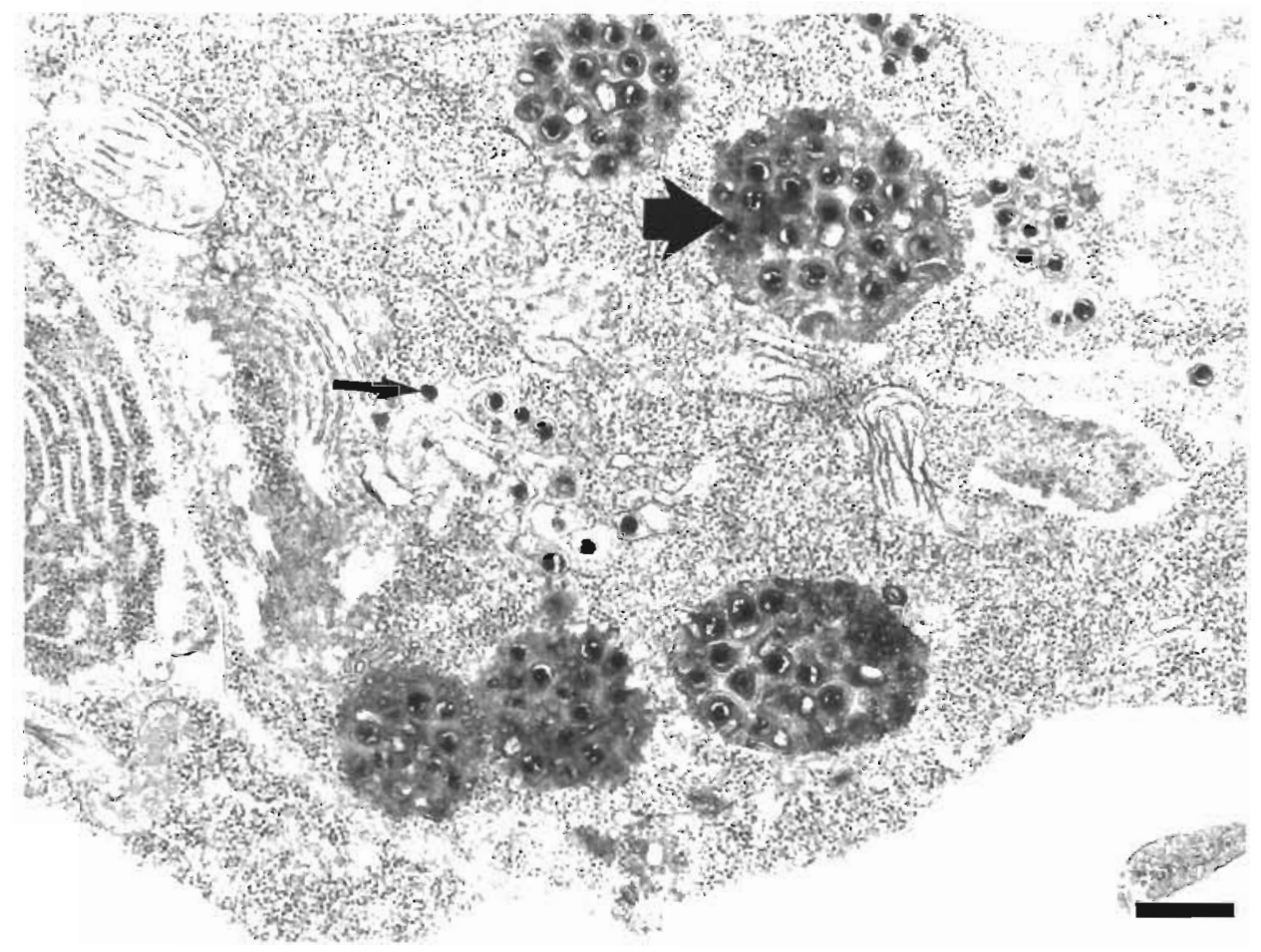



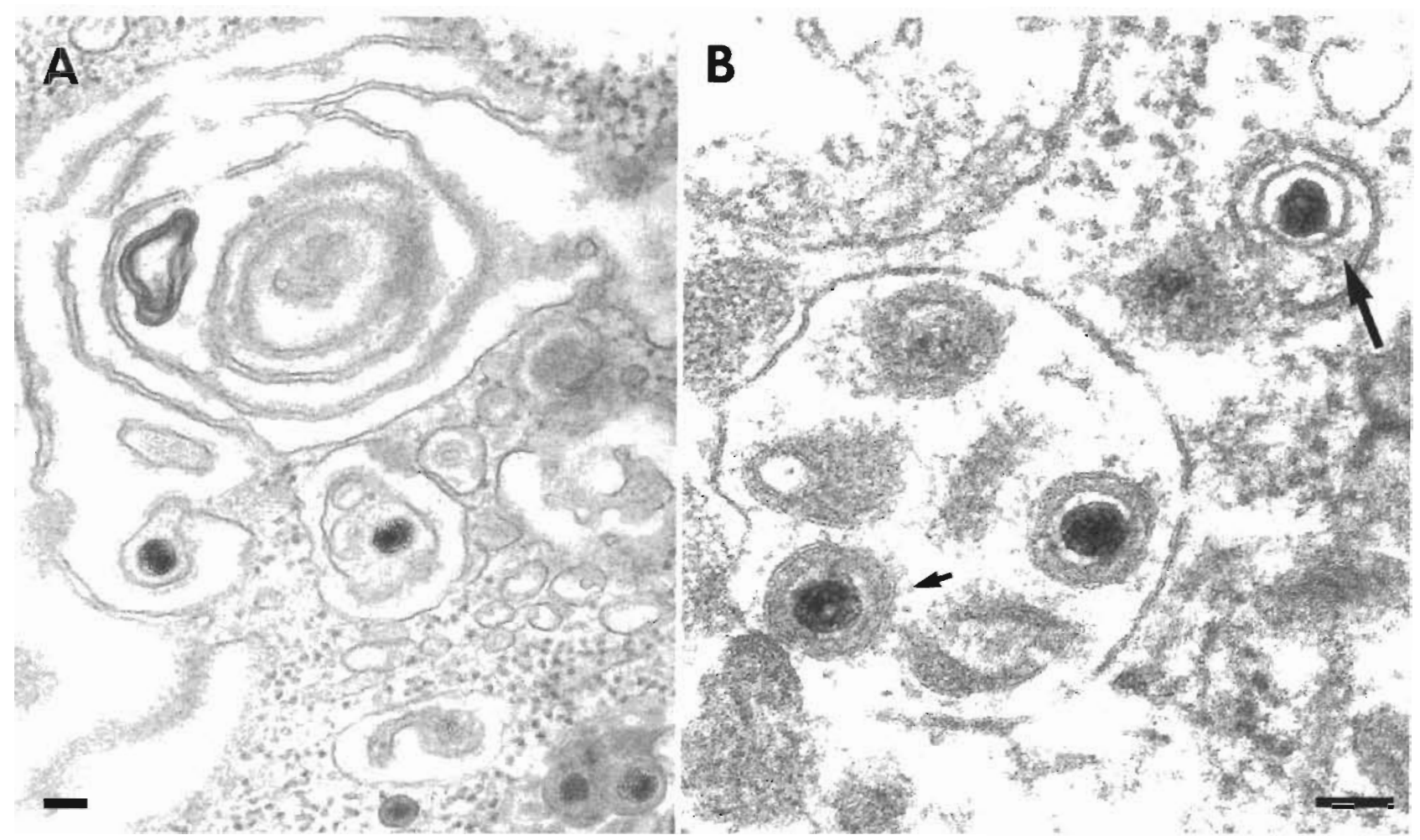

Fig 8. Enveloped virions within smooth-membraned vesicles. (A) Enveloped herpesviruses associated with the Golgı membrane system. (B) Enveloped virions within vesicles, large arrow vesıcle containing diffuse electron-dense material small arrow surface projections of an enveloped vinon Samples collected from affected pilchards, Rottnest Island, Western Australia Bars = 100 nm

moribund pilchards. Of the 162 unaffected pilchards examned (Table 1) only 5 were observed to contain herpesvirus. Significantly these 5 samples were collected $2 \mathrm{~d}$ before the mortality event at Iluka and were shown to be associated with developing gill lesions (Whittington et al 1997)

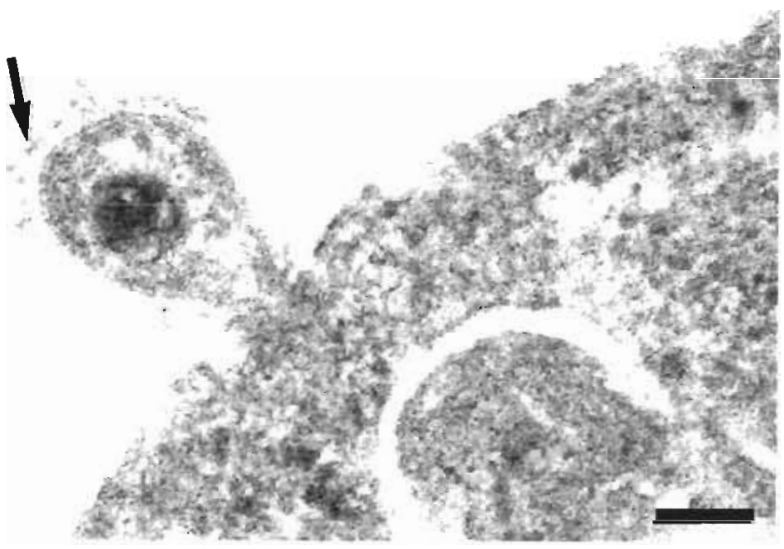

Fig. 9 Transmission electron micrograph of a herpesvirus budding from a gill epithelial cell. Arrow represents surface projections from an enveloped virion Sample collected from lluka, NSW (Australla) Bar $=100 \mathrm{~nm}$
The ultrastructural characteristics of the virus include the presence of a toroidal nucleosd, a tegument surrounding an icosahedral capsid (approximately $100 \mathrm{~nm}$ in diameter) and a surrounding envelope (up to $280 \mathrm{~nm}$ in diameter) contaming surface projections. The capsid possessed 5 capsomers on each edge of the icosahedral capsid, giving a total of 162 capsomers. Viruses were observed within both the nucleus and cytoplasm of infected cells. The presence of viruses within the nucleus infers that the virus has a DNA genome. Fine, granular, nuclear inclusions were observed in ultrathin sections and resembled those described within the nucles of channel catfish virus (CCV) infected cells (Wolf \& Darlington 1971) The overall low numbers of virus capsids and nucleocapsids within the nucles of the infected epithelial cells is similar to reports from herpesvirus-infected nuclei of angelfish (Mellergaard \& Bloch 19881, and CCV disease (Plumb et al 1974) A common characteristic of mammalian herpesvirus infected cells is the displacement of chromatin toward the nuclear mombrane (Murphy et al. 1995), thus was not observed within the infected pulchard epithelial cells nor has it been observed in some other herpesvirus infections of fish (Hedrick et al. 1990, 1991, Lee \& Whitf.eld 1992, Shchelkunov et al 1992, Steınhagen et al. 1992, Jung \& Mlyazaki 1995) 
Herpesvirus capsid and nucleocapsid envelopment is reported to take place at the nuclear membranes, where on the outer surface the virus obtains its tegument and surface proteins before accumulating in the endoplasmic reticulum and Golgi system where egress occurs by exocytosis (Nurphy et al. 1995). Alternatively, the enveloped virus may enter the cytoplasm by fusion of the envelope with the nuclear membrane (Buchanan et al. 1978, Kelly et al. 1983, Yamamoto et al. 1984, McAllister et al. 1985, Mellergaard \& Bloch 1988, Lee \& Whitfield 1992). Envelopment of nucleocapsids by budding through the nuclear membrane occurs in cells of some salmonids (Sano 1976, Kimura \& Yoshimizu 1989), walleye (Kelly et al. 1983) and Japanese flounder (Miyazaki et al. 1989). This morphogenic step was not observed within virus-infected epithelial cells of the pilchard. The apparent degeneration of the nuclear membranes may facilitate movement of naked (non-enveloped) capsids and nucleocapsids into the cytoplasm. This merging of nucleoplasm and cytoplasm has also been reported in CCV disease (Wolf \& Darlington 1971), Herpesvirus scophthalmi infection of turbot (Buchanan \& Madeley 1978), and goldfish herpesvirus disease (Jung \& Miyazaki 1995).

The final stages of virus morphogenesis remain unclear. The capsids and nucleocapsids acquired teguments from membrane-bound vesicles containing an electron-dense matrix similar to that described by Hedrick et al. (1991); the process(es) whereby this is achieved are not understood. Following this event the viruses appeared to either bud into smooth surfaced vesicles which were presumably components of the Golgi system or bud directly from the cell via the plasma membrane. These modes of envelopment have been reported for a range of fish viruses (Wolf \& Darlington 1971, Buchanan \& Madeley 1978, Mellergaard \& Bloch 1988, lida et al. 1989, 1991, Miyazaki et al. 1989, Hedrick et al. 1990, 1991).

The ultrastructural and morphogenic characteristics of this virus are consistent with those described for herpesviruses (Murphy et al. 1995, Roizman 1996). As membership in the family Herpesviridae is based upon the architecture of the virion [namely, the presence of an icosahedral core (approximately $100 \mathrm{~nm}$ in diameter) which contains 162 capsomers, a torus and the presence of a tegument and envelope with surface projections], the virus described in this paper can be placed in this family. Designation of the virus into a subfamily and genus awaits further studies of the genome, proteins and comparative serology. As no other herpesviruses have been identified from pilchards, we have tentatively named this virus 'pilchard herpesvirus'

Several theories have been considered to explain the mass mortalities of pilchards around Australia and
New Zealand including changes in water temperature due to an upwelling of cold water, toxic algal blooms and infectious disease (O'Neill 1995, Whittington et al. 1997). Recent data analyses indicate that there were no unusual oceanographic events such as an unusual cold upwelling off the Eyre Peninsula (Griffin et al. 1997) to account for the mass pilchard mortalities. The results of Whittington et al. (1997) showed that the pilchards suffered a sub-acute insult of the gills; the resultant lesions were not consistent with those associated with ichthyotoxic algae, siliceous algae, physiochemical factors, fungi, bacteria, dinoflagellates, amoeba or with other protozoa and metazoa. These conclusions are supported by Griffin et al. (1997), who reported that a low biomass of phytoplankton blooms was present during the large-scale pilchard mortalities on the west coast of Australia. Whittington et al. (1997) states that the pathology in affected fish from Australia and New Zealand could be the consequence of a herpesvirus pathogen.

Data presented in this paper show a correlation between overt virus replication within the gill epithelium and schools of pilchards in which large numbers of dead and moribund fish were observed. Data from Iluka (NSW, Australia) showed that lesions in the gill progressively developed from being mild and focal between 4 and $2 \mathrm{~d}$ before the mortality event to being generalised and severe during the mortalities (Whittington et al. 1997). By 8 d after the mortality event there were no lesions in the majority of gills examined. Electron microscopical examination of equivalent samples failed to detect herpesviruses until $2 \mathrm{~d}$ before and during the mortalities. Herpesviruses were not observed $8 \mathrm{~d}$ after the mortality event. Collectively the electron microscopical observations described in this paper and the results of Whittington et al. (1997) show a correlation between gill pathology, mortality events and the presence of a herpesvirus.

Epithelial hyperplasia has been reported in both freshwater and marine fish infected with herpesviruses (Békési et al. 1984, Bradley et al. 1989, Hedrick \& Sano 1989, Watson et al. 1995). In addition, there is evidence that Japanese flounder herpesvirus, epitheliotropic lake trout herpesvirus, and white sturgeon herpesvirus-2 may contribute to osmoregulatory failure among moribund fish (Watson et al. 1995). The observation of numerous detached and degenerating chloride cells within moribund pilchards may be indicative that pilchards infected with the virus are compromised in their ability to osmoregulate.

At this time, we have no evidence to suggest the involvement of another agent(s) with the reported mortalities (Griffin et al. 1997. Whittington et al. 1997) and therefore suggest that pilchard herpesvirus is the primary candidate responsible for the mass mortalities of 
pilchards in both Australia and New Zealand during 1995. Observations that only pilchards were affected support this suggestion. The observation that only adult pilchards were affected leads to the speculation that a specific physiological event may have been a contributing factor which in turn may have suppressed the immune system and thus left the adult pilchards vulnerable to infection. Whether the herpesvirus is the aetiological agent will remain unclear until transmission trials are conducted and Koch's postulates are fulfilled. Irrespective of the involvement of the virus in the pilchard mortalities, questions concerning its origin should be addressed.

The virus may represent a latent (enzootic) herpesvirus infection, a recent incursion and/or a crossspecies transmission. A common property of all known herpesviruses is that they can all remain latent within their natural hosts and, during periods of stress and under the appropriate stimulus, can replicate within the host and cause disease (Lee \& Whitfield 1992, Roizman 1996, Whitley 1996). If the virus is latent, then it must be assumed that Australian and New Zealand pilchards were already infected and the recrudescence of disease was initiated by an appropriate stimulus. It could be argued that a single environmental event in the form of an oceanographic disturbance (e.g. a change in water temperature due to an upwelling of cold water, phytoplanktonic blooms, elevated nitrate levels) may have been responsible for stimulating virus replication; however, hydrographic conditions were not uniformly unusual along the $6000 \mathrm{~km}$ Australain coast line where mortalities occurred during 1995 (Griffin et al. 1997). It is therefore unlikely that there was a single large-scale environmental stressor which triggered enzootic latent herpesvirus replication and disease. It should, however, be noted that Griffin et al. (1997) state that the environmental data collected from around Australia were not comprehensive and it is therefore possible that some environmental anomaly or anomalies did occur but were not recorded/observed. If changes in environmental conditions were the stimuli for virus replication, then the following question remains: Why have these massive mortalities never been observed before?

The focal origin of the epizootic and its spread around continental Australia is consistent with affected pilchard schools being naive populations, i.e. they had no previous exposure to the virus and therefore had not developed any degree of immunity. This interpretation infers that the pilchards were not host to endogenous/latent herpesvirus and its presence may be the result of a recent incursion, a cross-species transmission and or a new/emerging virus. The possibility of a cross-species transmission would seem unlikely as herpesviruses are considered host specific
(Lee \& Whitfield 1992); however, it should be noted that some herpesviruses such as cercopithecine herpesvirus 1 ( $\mathrm{B}$ virus) of Old World monkeys can cross species and be pathogenic for humans. There are many examples of newly emerging viruses e.g. rabbit haemorrhagic disease virus (Blancou 1991), equine morbillivirus (Murray et al. 1995), Ebola viruses, dolphin, porpoise and phocine morbilliviruses and Hantaan virus (Murphy \& Nathanson 1994) to name but a few. As the magnitude of pilchard mortalities and the associated pathology have not been described previously (Whittington et al. 1997), it could be argued that this is a new/undescribed infectious agent. If this is true, then questions also arise as to where the virus came from and what the events were that led to its emergence.

The possibility of the virus being a recent incursion into Australia and the mechanism by which it may have been introduced, e.g. importation of bait fish, migratory birds and ballast water from shipping, are discussed by Whittington et al. (1997).

The association of adult pilchards (pilchards larger than $11 \mathrm{~cm}$ ) with the mortalities adds another degree of complexity to the disease. Why were only specific size groups affected? This aspect of the disease could be explained if specific individuals were susceptible, i.e. their immune status was compromised by some physiological or environmental factor(s). As environmental stimuli appear to be unlikely factors contributing to the mortalities (Griffin et al. 1997), it is possible that some physiological factor may have contributed to specific size groups of pilchards being more susceptible to disease than others. This aspect of the disease will have to be addressed in any future transmission trials

To facilitate investigations into the origin and identification of the pilchard herpesvirus, antigen-and antibody-based assays must be developed in addition to the virus being tested against reference antisera to known piscine herpesviruses. The genome must also be studied and specific primers developed for use in polymerase chain reactions whereby it will be possible to examine affected and unaffected pilchards for the presence of herpesvirus-specific DNA. In the absence of a suitable cell culture system for the isolation of the virus, these assays would have the potential to detect the pilchard herpesvirus and determine whether it is an enzootic virus or a recent introduction into the Australian and New Zealand pilchard stocks.

\section{LITERATURE CITED}

Békés1 L, Kovacs-Gayer E, Ratz F, Turkovics O (1984) Skin infection of the sheatfish (Silurus glanis L) caused by a herpes virus. In: Olah J (ed) Fish pathogens and environ- 
ment in European polyculture. Akademai Kiado, Budapest. p 25-30

Blancou J (1991) Viral haemorrhagic disease of rabbits and the European brown hare syndrome. Rev Sci Tech Off Int Epizoot 10, p 263

Bradley TM, Medina DJ. Chang PW, McClain J (1989) Epizootic epitheliotropic disease of lake trout (Salvelinus namaycush): history and viral etiology. Dis Aquat Org 7 . $195-201$

Buchanan JS, Madeley CR (1978) Studies on herpesvirus scopthalmi infection of turbot Scophthalmus maximus (L.) ultrastructural observations. J Fish Dis 1:283-295

Buchanan JS, Richards RH, Sommerville C (1978) A herpestype virus from turbot (Scophthalmus maximus L.). Vet Rec 102:527-528

Copas C (1982) Mystery fish deaths. Professional Fisherman The Voice of Australasian Fishing Industry 4(6):24

Fijan N, Sulimanovic D, Bearzotti M, Muzinic D, Zwillenberg LO, Chilmonczyk S, Vautherot JF, de Kinkelin P (1983) Some properties of the Epitheliona papulosum cyprini (EPC) cell line from carp Cyprinus carpio. Ann Virol (Inst Pasteur) 134:207-220

Graham DH (1974) A treasury of New Zealand fishes. AH \& AW Reed, Wellington

Griffin DA, Thompson PA, Bax NJ, Bradford RW, Hallegraeff GM (1997) The 1995 Australian pilchard mass mortality: no role found for physical nor biological oceanographic factors in Australıa. Mar Freshwat Res (in press)

Hedrick RP, Groff JM, Okihiro MS, MCDowell TS (1990) Herpesviruses detected in papillomatous skin growths of koi carp (Cyprinus carpio). J Wildl Dis 26:578-581

Hedrick RP, McDowell TS, Groff JM, Yun S, Wingfield WH (1991) Isolation of an epitheliotropic herpesvirus from white sturgeon Acipenser transmontanus. Dis Aquat Org 11:49-56

Hedrick RP, Sano T (1989) Herpesviruses of fishes. In: Ahne W, Kurstak E (eds) Viruses of lower vertebrates. SpringerVerlag, New York, p 161-170

lida Y, Masamura K, Nakai T, Sorimachi M, Matsuda H (1989) A viral disease in larvae and juveniles of the Japanese flounder Paralichthys olivaceus. J Aquat Anim Health 1. $7-12$

Iida Y, Nakai T, Sorimachi M, Matsuda H (1991) Histopathology of a herpesvirus infection in larvae of Japanese flounder Paralichthys olivaceus. Dis Aquat Org 10:59-63

Jung SJ, Miyazaki T (1995) Herpesviral haematopoietic necrosis of goldfish, Carassius auratus (L.). J Fish Dis 18: $211-220$

Kelly RK, Nielsen O, Mitchell SC, Yamamoto, T (1983) Characterization of Herpesvirus vitreum isolated from hyperplastic epidermal tissue of walleye, Stizostedion vitreum vitreum (Mitchill). J Fish Dis 6:249-260

Kimura T, Yoshimizu M (1989) Salmon herpesvirus: OMV, Oncorhynchus masou virus. In: Ahne W. Kurstak E (eds) Viruses of lower vertebrates. Springer-Verlag, Berlin, p 171-183

Lee S, Whitfield PJ (1992) Virus-associated spawning papillomatosis in smelt, Osmerus eperlanus L., in the River Thames. J Fish Biol 40:503-510

MCAllister PE, Lidgerding BC, Herman RL, Hoyer LC, Hankins J (1985) Viral diseases of fish: first report of carp

Responsible Subject Editor: F. M. Hetrick, College Park, Maryland, USA pox in golden ide (Leuciscus idus) in North America. J Wildl Dis 21:199-204

Mellergaard S, Bloch B (1988) Herpesvirus-like particles in angelfish Pterophyllum altum. Dis Aquat Org 5:151-155

Miyazaki T, Fujiwara K, Kobara J, Matsumoto N, Abe M, Nagano T (1989) Histopathology associated with two viral diseases of larval and juvenule fishes: epidermal necrosis of the Japanese flounder Paralichthys olivaceus and epithelial necrosis of black sea bream Acanthopagrus schlegeli. J Aquat Anim Health 1:85-93

Murphy FA, Fauquet CM, Bishop DHL, Ghabrial SA, Jarvis AW, Martelli GP, Mayo MA, Summers MD (1995) Virus taxonomy: classification and nonmenclature of viruses: Sixth Report of the International Committee on the Taxonomy of Viruses. Springer-Verlag, Wien, p 114-127

Murphy FA, Nathanson N (1994) The emergence of new virus diseases: an overview. Semin Virol 5:87-102

Murray K, Selleck P, Hooper P, Hyatt A, Gould A, Gleeson L, Westbury H, Hiley L, Selvey L, Rodwell B, Ketterer P (1995) A morbillivirus that caused fatal disease in horses and humans. Science 268:94-95

O'Neill G (1995) Ocean anomoly triggers record fish kill. Science 268:1431

Plumb JA, Gaines JL, Mora EC, Bradley GG (1974) Histopathology and electron microscopy of channel catfish virus in infected channel catfish, Ictalurus punctatus (Rafinesque). J Fish Biol 6:661-664

Roizman B (1996) Herpesviridae. In: Fields BF, Knipe DM Howley PM (eds) Field virology, Vol 2. Lippincott-Raven, Philadelphia, p 2221-2230

Sano T (1976) Viral diseases of cultured fishes in Japan. Fish Pathol 10:221-226

Shchelkunov IS, Karaseva TA, Kadoshnikov YUP (1992) Atlantic salmon papillomatosis: visualization of herpesviruslike particles in skin growths of affected fish. Bull Eur Assoc Fish Pathol 12:28-31

Smith P (1995) Pilchard deaths in New Zealand. Seafood New Zealand $3: 26-29$

Steinhagen D, Kruse P, Neukirch M (1992) Virus-associated epidermal hyperplasia in golden ide Leuciscus idus melanotus. Dis Aquat Org 13:225-229

Watson LR, Yun SC, Groff JM, Hedrick RP (1995) Characteristics and pathogenicity of a novel herpesvirus isolated from adult and subadult white sturgeon Acipenser transmontanus. Dis Aquat Org 22:199-210

Whitley RJ (1996) Cercopithecine herpes virus 1 (B virus). In Fields NF, Knipe DM, Howley PM (eds) Field virology, Vol 2. Lippincott-Raven, Philadelphia, p 2623-2635

Whittington RJ, Jones B. Hine PM, Hyatt AD (1997) Epizootic mortality in the pilchard (Sardinops sagax neopilchardus) in Australia and New Zealand in 1995. I. Pathology and epizootiology. Dis Aquat Org 28:1-16

Whittington RJ, Steiner K (1993) Epizootic haematopoietic necrosis virus (EHNV): improved ELISA for detection in fish tissues and cell cultures and an efficient method for release of antigen from tissues. J Virol Methods 43:205-220

Wolf K, Darlington RW (1971) Channel catfish virus: a new herpesvirus of ictalurid fish. J Virol 8:525-533

Yamamoto T, Kelly RK, Nielson O (1984) Epidermal hyperplasias of northern pike (Esox lucius) associated with herpesvirus and C-type particles. Arch Virol 79:255-272

Manuscript first received: May 7, 1996

Revised version accepted: September 24, 1996 